\title{
Influence of Feed Withdrawal Period on Growth Performance of Broiler Chickens under High Ambient Temperature
}

\author{
Ahmed Ali Saleh", Abdul Rahman Ali Alkhamisi, Ahmed Mousa Abdul Rahman, \\ Moustafa Al-Sayed Albayomy and Mohamed Salah Draz \\ Department of Poultry Production, Faculty of Agriculture, Kafrelsheikh University, \\ 333516 Kafrelsheikh, Egypt
}

\begin{abstract}
This experiment was conducted to evaluate the effect of feed withdrawal period on growth performance of broiler chickens. A total of 180 chicks at one day of age were randomly divided into three experimental groups with 6 replicates of 10 birds each. The first experimental group of chicks was fed basal diets (commercial broilers diets $23 \%$ crude protein as starter; $21 \%$ crude protein as grower and $19 \%$ crude protein as finisher, respectively, until 35 days of age) and served as the control group. The second experimental group was fed the same control diet but the feed withdrawal for one hour per day at night was performed. The third group fed the same control diets but the feed withdrawal for two hours per day and one hour at the afternoon and one hour at night (from 8-35 days of age) was performed. While feed consumption was not different among these three groups, both final body weight and body weight gain were higher in chicks treated with feed withdrawal for $2 \mathrm{~h} / \mathrm{d}$; however feed conversion ratio decreased. Feed withdrawal $2 \mathrm{hr} / \mathrm{d}$ decreased abdominal fat compared with the control group, while, carcass, muscles, liver and gizzard weights were not affected. Furthermore, feed withdrawal decreased plasma total cholestrol, while neither glutamate oxaloacetate transaminase (GOT) nor glucose was affected. It could be concluded that feed withdrawal had positive effects on growth performance and plasma lipid profiles in broilers chickens.
\end{abstract}

Keywords: Feed withdrawal, Broilers, Growth performance, Plasma lipid profiles, Glucose, Abdominal fat, Cholesterol.

\section{Introduction}

Growing broilers in summer season in Egypt is a problematic owing to the direct effect of high ambient temperature. In broiler production farms, environmental temperature higher than $30^{\circ} \mathrm{C}$ resulted in heat stress which considered one of the most common stressors in poultry production. In Egypt, the open-sided farms cannot control the microclimate in the broiler house (Saleh et al., 2018). Metabolic heat production associated with feeding and digestion can be a significant contributor to heat stress on broilers, especially, during the afternoon and mid-day (Abdul Azis and Afriani, 2017). It has been shown that heat production is associated with feed consumption and metabolism. Thus, reduction feed intake can help birds withstand heat stress by decreasing their rate of heat production. For this reason feed withdrawal during summer days is recommended to address this heat stress problem and it has become a common management practice in different broiler producing areas (Ozkan et al., 2003). Moreover, feed restriction is a method of feeding in which the time or duration or amount of feed is limited. In general, the feed restriction is carried out by quantitative and qualitative feed restriction methods (David and Subalini, 2015). In broiler chickens, the feed cost encompasses more than $70 \%$ of the total production cost. Restricted feeding for the broiler chickens prevents the feed wastage and thereby minimizes the cost of production (Jalal and Zakaria, 2012). In addition, the fat deposition in the broiler chickens could be minimized through the restricted feeding (McMurtry et al., 1988). The broilers with heavy deposit of abdominal fat indicate poor finishing.

*Correspondence author: E-mail: ahmed.saleh1@agr.kfs.edu.eg 
Furthermore, the fat deposition reduces the carcass quality and feed efficiency leading to less demand by the consumers. Moreover, the fat deposition may cause the metabolic diseases leading to mortality in the broiler chickens (Clement et al., 2010). The aim of this study was to evaluate the effect of feed withdrawal period on growth performance, organs weight and blood parameters in broiler under high ambient temperature.

\section{Materials and Methods}

\section{Birds and experimental design}

This experiment was carried out in stratification with the guidelines of the Poultry Production Department, Faculty of Agriculture, Kafrelsheikh University, Egypt. A total of 180, one-day-old broilers (Ross 308) were housed in open system farm, and provided with water and commercial starter, grower and finisher diets (corn and soybean meal based diet containing $23 \%$ crude protein and $2950 \mathrm{kcal} / \mathrm{kg} \mathrm{ME}$ for starter diet; $21 \% \%$ crude protein and $3040 \mathrm{kcal} /$ $\mathrm{kg}$ ME for grower and 19\%\% crude protein and $3140 \mathrm{kcal} / \mathrm{kg} \mathrm{ME}$ for finisher, respectively) until 35 days of age. The birds were haphazardly divided into 3 groups with 6 replicates of 10 birds each to tie average of body weight in each group; the control group was fed the basal diets ad libitum fed birds. The second experimental group was fed the same control diets but the feed withdrawal for one hour per day at night was performed. The third group fed the same control diets but the feed withdrawal for two hours per day and one hour at afternoon and one hour at night, respectively (from 8-35 days of age). The nutrient compositions of the basal diets are shown in Table 1. The experiment was conducted in open door farm with $24 \mathrm{~h}$ light. The temperature of the animal room was optioned $26-32{ }^{\circ} \mathrm{C}$ throughout the experiment. Body weight was recorded every week, and feed consumption was recorded daily during the experimental period. At the end of the experimental period, the birds were weighted and slaughtered by decapitation then dissected to measure the weights of carcass and organs. Blood samples were collected from neck into heparinized test tubes quickly centrifuged $(3,000$ rpm for $20 \mathrm{~min}$ at $5{ }^{\circ} \mathrm{C}$ ) to separate the plasma. Plasma was stored at $-20^{\circ} \mathrm{C}$ pending analysis.

\section{Biochemical analysis}

Plasma total cholesterol, glutamic oxalacetic transaminase (GOT), and glucose concentrations were measured colorimetrically by using commercial kits (Diamond Diagnostics, Egypt) according to the procedure outlined by the manufacturer according to Saleh (2013).

\section{Statistical analysis}

The differences between the treatments and the control were analyzed with a General Liner model using SPSS Statistics 17.0 (Statistical Packages for the Social Sciences, released 23 August 2008). Tukey's multiple comparison test was used to identify which treatments conditions were significantly different from each other at a significance level of $p<0.05$.

\section{Results}

The effect of feed withdrawal period on body weight gain, feed intake, and feed conversion ratio were summarized in Table 2. Feed withdrawal for two hours per day increased final body weight and body weight gain significantly, while feed consumption was not differed in all experimental groups when compared to the ad libitum fed birds. Consequently, feed conversion ratio was significantly decreased. Table 3 shows that the response of the organs weights by feed withdrawal period. Abdominal fat weight was decreased significantly by feed withdrawal for two hours per day while; carcass, muscles, liver, gizzard, heart and spleen were not affected. Figure 1 shows plasma concentrations of glucose, total cholesterol and GOT. Plasma total cholesterol concentration was decreased, while, plasma glucose and GOT were not affected by feed withdrawal period.

\section{Discussion}

Results of the current experiment indicated that feed withdrawal increased final body weight and body weight gain, while, it reduced feed conversion ratio when compared to the ad libitum fed birds. Significantly similar improved in body weight gains in the feed restricted birds when compared to the ad libitum fed birds could be due to the improved feed efficiency in the feed restricted birds were reported in several previous studies (Fontana et al., 1992; Zhong et al., 1995; Zubair and Leeson, 1995; Clement et al., 2010). Another research study reported that the broiler chickens kept under feed withdrawal for 5 and 7 hours from 8th to 28th day, gained less body weight than those kept under ad libitum (Mahmood et al., 2007). Furthermore, the feed restricted birds obtained low weight than full-fed birds reported by Palo et al. (1995). However, the growth performance of the birds has been higher by the time duration of feed restriction in the current experiment. 
TABLE 1. Ingredients and nutrient composition of the basal diets

\begin{tabular}{|c|c|c|c|}
\hline Ingredients & Starter $(\mathrm{g} / \mathrm{kg})$ & Grower (g / kg) & Finisher (g / kg) \\
\hline Yellow corn & 548 & 595 & 650 \\
\hline Soybean meal, $46 \%$ & 380 & 328 & 254 \\
\hline Corn gluten meal, $62 \%$ & 13 & 14 & 27 \\
\hline Soy oil & 19 & 25 & 30 \\
\hline Limestone & 10 & 10 & 9.5 \\
\hline Dicalcium phosphate & 17.5 & 15.5 & 15 \\
\hline Premix $^{1}$ & 3 & 3 & 3 \\
\hline Sodium bicarbonate & 1.6 & 1.5 & 1.8 \\
\hline Salt & 3.5 & 3.5 & 3.5 \\
\hline L-Lys $\mathrm{HCl}$ & 1 & 1.3 & 1.4 \\
\hline DL-Met & 2.6 & 2.5 & 1.8 \\
\hline L- threonine & 0.2 & 0.2 & 0.2 \\
\hline Potassium Carbonate & 0.6 & 0.5 & 2.8 \\
\hline \multicolumn{4}{|l|}{ Nutrient composition ${ }^{2}$} \\
\hline $\mathrm{CP}, \%$ & 23 & 21 & 19 \\
\hline $\mathrm{ME}, \mathrm{Kcal} / \mathrm{Kg}$ & 2950 & 3040 & 3140 \\
\hline $\mathrm{Ca}, \%$ & 0.89 & 0.83 & 0.78 \\
\hline Total P, \% & 0.72 & 0.67 & 0.63 \\
\hline $\mathrm{Na}, \%$ & 0.20 & 0.20 & 0.20 \\
\hline $\mathrm{CL}, \%$ & 0.25 & 0.25 & 0.25 \\
\hline
\end{tabular}

*Each $3 \mathrm{~kg}$ of vitamin-mineral premix contain: $6000000 \mathrm{IU}$ vit A, $900000 \mathrm{IU}$ vit $\mathrm{D}_{3}, 40000 \mathrm{mg}$ vit E, 2000mg vit K, 2000mg vit.B1, 4000mg vit B2, 2000mg vit B6, 10mg vit B12, 50000mg Niacin, $10000 \mathrm{mg}$ pantothenic acid, 50mg Biotin, 3000mg Folic acid, $250000 \mathrm{mg}$ choline, 8500mg Mn, 50000mg Fe, 50000mg Cu, 200mg I, 100mg Se and 100mg Co.

\section{TABLE 2. Effect of feed withdrawal period on performance of broiler chickens}

\section{Control, Ad libitum $\quad 1 \mathrm{hr} / \mathrm{day}$ feed withdrawal $2 \mathrm{hr} / \mathrm{day}$ feed withdrawal}

\begin{tabular}{lccc}
\hline Initial Body weight, g & $42.2 \pm 0.2$ & $42.6 \pm 0.3$ & $42.4 \pm 0.2$ \\
Final body weight, g/35day & $2306 \pm 21 \mathrm{~b}$ & $2340 \pm 24 \mathrm{ab}$ & $2481 \pm 17 \mathrm{a}$ \\
Body weight gain & $2263.8 \pm 18 \mathrm{~b}$ & $2297.4 \pm 21 \mathrm{ab}$ & $2438.6 \pm 19 \mathrm{a}$ \\
Feed intake, g & $3511.5 \pm 14$ & $3348 \pm 15$ & $3511.8 \pm 18$ \\
FCR & $1.526 \pm 0.08 \mathrm{a}$ & $1.435 \pm 0.05 \mathrm{ab}$ & $1.416 \pm 0.04 \mathrm{~b}$
\end{tabular}

Values presented are means and their standard error (SE). ${ }^{\mathrm{a}, \mathrm{b}}$ Mean values followed by different letters in the same row are significantly different $(\mathrm{P}<0.05)$. 
TABLE 3. Effect of feed withdrawal period on organs weights of broiler chickens

\begin{tabular}{lccc}
\hline & Control, Ad libitum & $\begin{array}{c}\text { 1hr/day feed } \\
\text { withdrawal }\end{array}$ & 2hr/day feed withdrawal \\
\hline Carcass weight, g/100g bw & $78.8 \pm 1.7$ & $78.7 \pm 1.6$ & $77.1 \pm 0.32$ \\
Breast muscle weight, g/100g bw & $21.6 \pm 1.1$ & $23.8 \pm 0.4$ & $22.9 \pm 0.38$ \\
Thigh muscle weight, g/100g bw & $16.5 \pm 1.2$ & $16.4 \pm 0.6$ & $16.7 \pm 0.51$ \\
Liver weight, g/100g bw & $1.96 \pm 0.17$ & $2.28 \pm 0.19$ & $1.99 \pm 0.14$ \\
Gizzard weight, g/100g bw & $1.11 \pm 0.04$ & $1.14 \pm 0.02$ & $1.24 \pm 0.07$ \\
Heart weight, g/100g bw & $0.46 \pm 0.03$ & $0.44 \pm 0.04$ & $0.45 \pm 0.01$ \\
Spleen weight, g/100g bw & $0.148 \pm 0.01$ & $0.110 \pm 0.01$ & $0.163 \pm 0.02$ \\
Abdominal fat weight, g/100g bw & $1.69 \pm 0.21 \mathrm{a}$ & $1.43 \pm 0.14 \mathrm{ab}$ & $1.12 \pm 0.06 \mathrm{~b}$
\end{tabular}

Values presented are means and their standard error (SE). ${ }^{\mathrm{a}, \mathrm{b}}$ Mean values followed by different letters in the same row are significantly different $(\mathrm{P}<0.05)$.

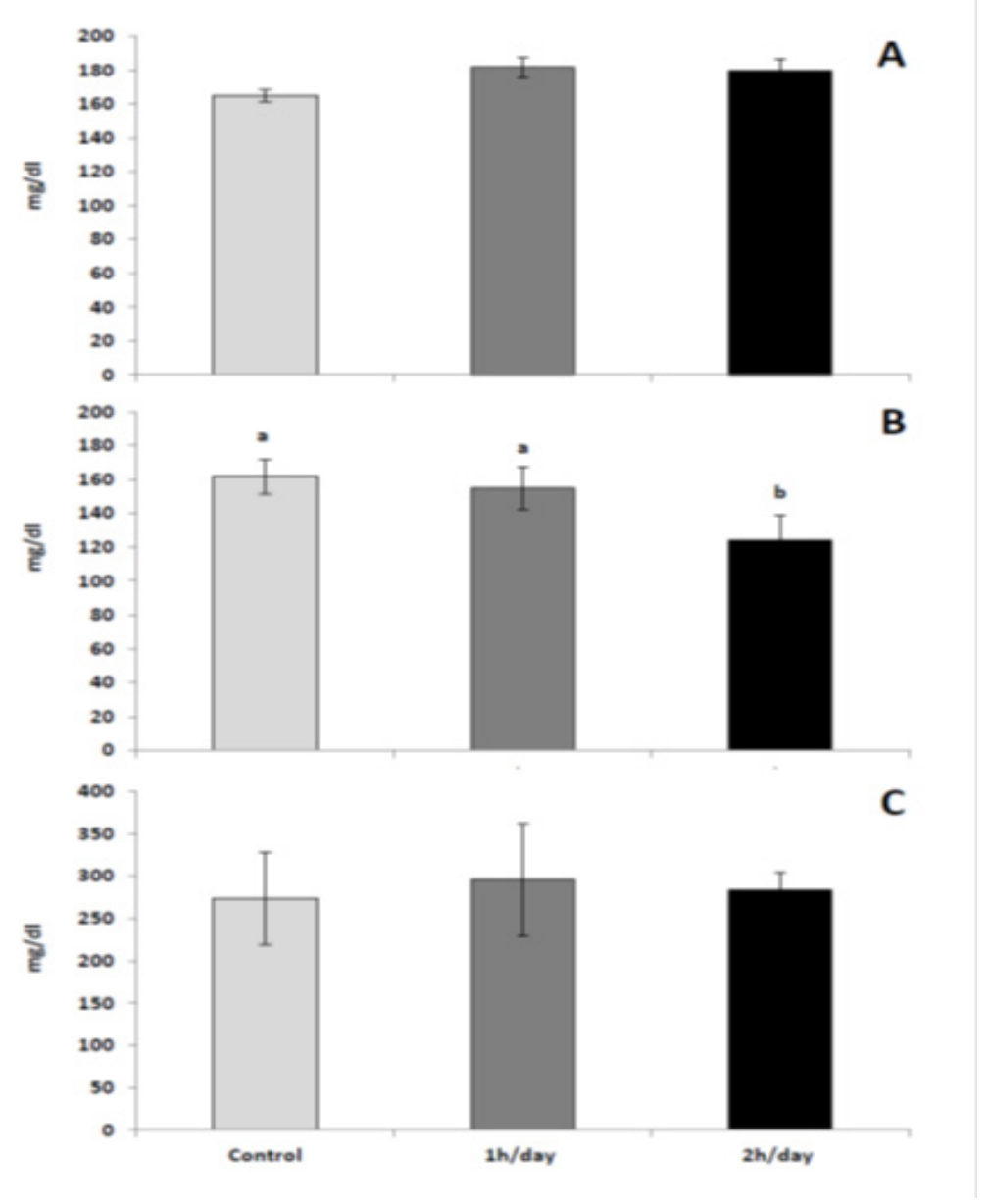

Fig. 1 . Effect of feed withdrawal period on blood parameters of broiler chickens. Plasma glucose (A), plasma total cholesterol (B) and plasma GOT (C). Values are expressed as mean \pm standard error; mean values with different letters are significantly different from each other $(\mathrm{P}<\mathbf{0 . 0 5})$ 
Feed withdrawal decreased abdominal fat in this study, while, carcass and organs' weights were not affected. This finding is supported by other previous experiments in broiler chickens (Ramlah et al., 1996) and growing rabbits (Tůmová et al., 2016; Saleh et al., 2013) which indicated that feed restriction reduced abdominal fat. Also, liver, heart and gizzard weights were in the normal weights after feed withdrawal. However, abdominal fat weight was reduced in feed withdrawal for 8 hours compared with control group reported by Petek (2000). Moreover, Demir et al. (2004) found that abdominal fat weight was decreased by 8 and 16 hours feed withdrawal.

Similar research study reported that no significant difference for the dressing percentage among the broiler chickens fed quantitatively restricted feed and the birds fed ad libitum (Jalal and Zakaria, 2012). However, another study reported that the dressing percentage of broiler chickens was significantly reduced by the restricted feeding (Saleh et al. 2005). In contrast, significantly increased dressing percentage was reported in broiler chickens fed restricted by feed withdrawal of 3 hours per day during day 21-42experimental period when compared to the full-fed birds (De Silva et al., 2012; Saleh et al., 2018). Sarica et al. (1995) found that no significant effect on gizzard weight, while liver and heart weights between 0-12 hours after feed withdrawal were significantly reduced.

No significant differences between treatments were observed on plasma glucose and GOT, while; plasma total cholesterol concentration was decreased by feed withdrawal for 2 hours. These results are in agreement with Fiky et al. (2008) who reported that presented the feed in two times per day, increased serum total protein and globulin significantly, while serum total lipids and total cholesterol were decreased . Also, Renema et al. (1999) and Rajman et al. (2006) found that plasma lipids and total cholesterol were decreased while glucose was not affected by feed restriction. Moreover, Ebeid et al. (2012) illustrated that feed restriction reduced plasma total cholesterol, triglycerides and non-esterifed fatty acids in growing rabbits.

\section{Conclusion}

It could be concluded that growth performance may be improved and abdominal fat might be decreased by feed withdrawal when compared with the birds fed ad libitum from 8-35 days of age.

\section{Conflict of Interest Statement}

This manuscript has no conflicts of interest.

\section{Acknowledgements}

The authors wish to acknowledge the helpful suggestions of members of department of poultry production, faculty of agriculture, Kafrelsheikh University, Egypt.

This research received no specific grant from any funding agency in the public, commercial or not-for-profit sectors.

\section{References}

Abdul Azis, A. and Afriani, A. (2017) Effect of feeding time restriction during the growing period on growth performance of broiler chickens. Asian J. of Poult. Sci. 11, 70-74.

Clement, I.M., Ibrahim, D.K., Joseph, I., Iro, N., Ibrahim, D.M. and Bruce, H. (2010) Carcass and blood components of broiler chickens fed sorghum or millet as replacement for maize in the semi arid zone of Nigeria. Agr. and Biology J. of North America. 1, 326-329.

David, L.S. and Subalini E. (2015) Effects of Feed restriction on the growth performance, organ size and carcass characteristics of Broiler chickens. Scholars J. of Agri. and Veterinary Sci. 2 (2A), 108-111.

De Silva, P.H.G.J. and Kalubowila, A. (2012) Influence of feed withdrawal for three hour time period on growth performance and carcass parameters later stage of male broiler chickens. Iranian J. of Applied Anim. Sci. 2 (2), 191-197.

Demir, E., Sarica, S., Sekeroglu, A., Özcan, M.A. and Seker, Y. (2004) Effects of early and late feed restriction or feed withdrawal on growth performance, ascites and blood constituents of broiler chickens. Acta Agri. Scand. 54, 152-158.

Ebeid, T., Tůmová E. and Volek, Z. (2012) Effects of a one week intensive feed restriction in the growing rabbit: Part 1 - Performance and blood biochemical parameters. The 10 th World Rabbit Congress, 3-6 September 2012, Sharm El-Sheikh, Egypt, pp. $607-$ 611.

El-fiky, A., Soltan, M., Abdou, F.H., El- Samra, S. and El- Neney, B. (2008) Effect of light regime and feeding frequency on some productive, physiological traits and hormonal profiles in broiler chicks. Egypt. Poult. Sci. 28,711-743.

Fontana, E.A., Weaver, W.D., Watkins, B.A. and J. Sus. Agric. Sci.45, No. 2 (2019) 
Denbow, D.M. (1992) Effect of early feed restriction on growth, feed conversion and mortality in broiler chickens. Poult. Sci. 71 (8), 1296-1305.

Jalal, M.A.R. and Zakaria, H.A. (2012) The Effect of quantitative feed restriction during the starter period on compensatory growth and carcass characteristics of broiler chickens. Pakistan J. Nut. 11 (9), 719-724.

Mahmood, S., Mehmood, S., Ahmad, F., Masood, A. and Kausar, R. (2007) Effects of feed restriction during starter phase on subsequent growth performance, dressing percentage, relative organ weight and immune response of broilers. Pakistan Vet. J. 27, 137-141.

McMurtry, J.P., Rosebrough, R.W., Plavnik, I., and Cartwright, A.I. (1988) Influence of early plane of nutrition on enzyme systems and subsequent tissue deposition. In: Biomechanisms Regulating Growth and Development. $1^{\text {st }}$ edition, Steffens GL, Rumsey TS Ed., Dordrecht, the Netherlands. 329- 341.

Ozkan, S., Akbas,Y., Altan, O., Altan, A., Ayhan, V. and Ozkan, K. (2003) The effect of short- term fasting on performance traits and rectal temperature of broilers during the summer season. Br. Poult Sci. 44, 88-95.

Palo, P.E., Sell, J.L., Piquer, F.J., Vilaseea, L. and Soto- Salanova, M.F. (1995) Effect of early nutrient restriction on broiler chickens performance and digestive enzyme activities. Poult. Sci. 74, 14701483.

Petek, M. (2000) The effects of feed removal during the day on some production traits and bloodparameters of broilers. Tr. J. Anim. Sci. 24, 447- 452.

Rajman, M., Jurani, M., Lamosova, D., Macajova, M., Sedlackova, M., Kostal, L., Jezova, D. and Vyboh, P. (2006) The effects of feed restriction on plasma biochemistry in growing meat type chickens (Gallus gallus). Comparative Biochemistry and Physiology; part A 145, 363-371.

Ramlah, A.H., Halim, A.S. and Siti-Sara, A.R. (1996) Effects of early feed restriction on the performance of broilers. Asian-Australasian J. of Anim. Sci. 9 (1), 63-67.

Renema, R.A., Robinson, F.E., Newcombe, M., and McKay, R. I. (1999) Effects of body weight and feed allocation during sexual maturation in broiler breeder hens growth and carcass characteristics. Poult. Sci.78, 619-628.
Saleh, E.A., Watkins, S.E., Waldroup, A.L. and Waldroup, P.W. (2005) Effects of early quantitative feed restriction on live performance and carcass composition of male broilers grown for further processing. J. Applied Poult. Res. 14, 87-93.

Saleh, A.A. (2013) Effects of fish oil on the production performances, polyunsaturated fatty acids and cholesterol levels of yolk in hens. Emirates $J$. of Food and Agri. 25, 605 -661.

Saleh, A.A., Ohtsuka, A., Yamamoto, M. and Hayashi, K. (2013) Aspergillus awamori Feeding Modifies Lipid Metabolism in Rats. Bio.Med. Res. Internationl.vol. 2013, Article ID 594393, 7 pages, 2013. https://doi.org/10.1155/2013/594393.

Saleh, A.A., Ragab, M.M., Enas, A.M., Abudabos, A., and Ebeid, T.A. (2018) Effect of dietary zinc-methionine supplementation on growth performance, nutrient utilization, antioxidative properties and immune response in broiler chickensunder high ambient temperature. $J$. Applied Anim. Res. 46, (1) 820-827.

Saleh, A.A., Ebeid, T.A. and Abudabos, A.M. (2018) Effect of dietary phytogenics (herbal mixture) supplementation on growth performance, nutrient utilization, antioxidative properties, and immune response in broilers. Environ. Sci. Pollut. Res. 25, 14606-14613.

Sarica, M., Karaçay, N. and Çam, M.A. (1995) Kesim öncesi degisik açlik periyodlarinin etlik piliçlerde bazi kesim ve karkas özelliklerine etkileri. Tr. $J$. Vet. Anim. Sci. 19, 303-307.

Tůmová, E., Volek, Z. Chodová, D., Härtlová, H., Makovický, P., J. Svobodová, T. A. Ebeid and L. Uhlírová (2016). The effect of 1-week feed restriction on performance, digestibility of nutrients and digestive system development in the growing rabbit. Animal, 10, 1-9.

Zhong, C., Nakaue, H.S., Hu, C.Y. and Mirosh, L.W. (1995) Effect of full feed and early feed restriction on broiler performance, abdominal fat level, cellularity and fat metabolism in broiler chickens. Poult. Sci. 74, 1636-1643.

Zubair, A.K. and Leeson, S. (1996) Compensatory growth in the broiler chicken: a review. World's Poult. Sci. 52,189-201. 


$$
\begin{aligned}
& \text { تأثير فترات سحب العلف علي الاداء الانتاجي لكتاكيت التسمين المرباة تحت ظروف درجات } \\
& \text { أحمد علي صالح ،عبدالرجمن علي الخميسي ، أحمد موسي عبدالرحمن ، مصطفي السبد البيومي و محمد } \\
& \text { صلاح دراز } \\
& \text { قسم انتاج الدو اجن - كلية الزر اعة - جامعة كفر الثيخ - مصر }
\end{aligned}
$$

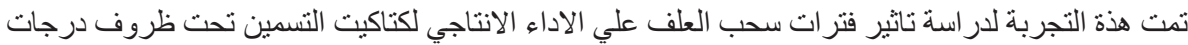

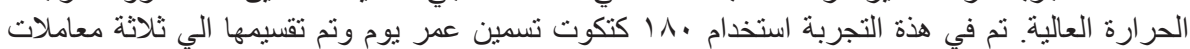



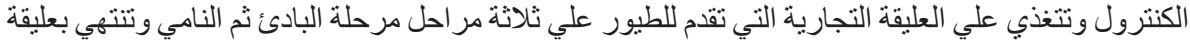

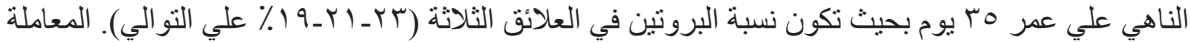

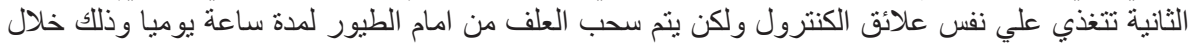

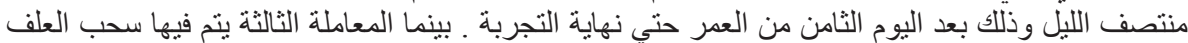



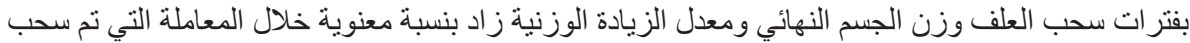

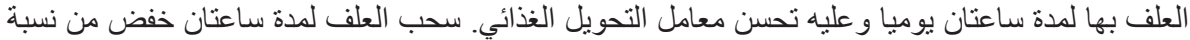





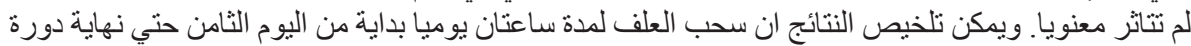
التربية له ناثير ايجابي علي النمو وكذلك تحسن من نو عية الدهون في الدم في كتاكيت التنمين.
} 